\title{
La imaginación en la tradición metafísico-mística: de Platón a Marsilio Ficino
}

\author{
ALICJA WALERICH \\ Wyższa Szkoła a Filologiczna (Wrocław, Polonia) \\ alicja.walerich@gmail.com
}

\begin{abstract}
Resumen
El objetivo de este artículo es examinar el papel de la imagen y de la imaginación desde la perspectiva del proceso ternario místico basado en la tradición del Pseudo Dionisio Areopagita. Destaco en este proceso la etapa primera relacionada con la teología simbólica y la experiencia exterior y sensorial; la etapa intermedia relacionada con el conocimiento racional y con la experiencia interior; la etapa tercera relacionada con la teología mística, esto es con la experiencia sobrenatural. Llego a la conclusión de que en la primera etapa la imaginación sobrepasa lo exterior y lo superficial que se le atribuía tradicionalmente, porque varios autores metafísicos y místicos introducen en su contexto un momento de la comprensión intuitiva. En la segunda etapa la imaginación no sólo es un fundamento del pensamiento discursivo, sino que también constituye un ejercicio espiritual que ha de intensificar el proceso pensativo. En la tercera etapa la imagen y la imaginación son un medio que ayuda a vencer la inefabilidad de la experiencia mística.
\end{abstract}

Palabras claves: imagen, imaginación, teología mística, fantasía, teología simbólica, pensamiento.

\section{Imagination in the metaphysical and mystical tradition: from Plato to Marsilio Ficino}

\begin{abstract}
The objective of the article is to examine the role of the image and imagination from the perspective of the tripartite mystical process based on the tradition of Psendo-Dionysius the Areopagite. I distinguish in the first stage of this process the symbolical theology related to the external and sensuous experience; in the second stage the rational cognition and internal experience; in the last stage the mystical theology related to the supranatural experience. I arrive at a conclusion that in the first stage the imagination exceed the exterior and superficial character which was attributed traditionally to it, because various metaphysical and mystical authors introduce in the context of it a moment of a intuitive comprehension. In the second stage it is not only a basis of discursive thinking but it constitutes spiritual exercise which should intensify the process of thinking. In the third stage the image and imagination are a medium which belp to overcome the ineffability of the mystical experience.
\end{abstract}

Key words: imagen, imagination, mystical theology, phantasia, symbolical theology, thinking.

Doctora en Ciencias Humanas (Ciencia de la literatura) por la Universidad de Wrocław (Polonia). Trabaja como docente en Wyższa Szkoła Filologiczna en Wrocław. Su publicación más importante es una monografía dedicada al papel de la imagen y de la imaginación en san Juan de la Cruz y Edith Stein (2013). 
En la tradición metafísico-mística — en la que se divide el alma en la esfera sensual y espiritual- se atribuye la imaginación a lo exterior: a los sentidos ( $\alpha$ l゙$\theta \eta \sigma \iota \varsigma$, sensus), o a lo más interior: al pensamiento (vous, mens). La imaginación acompaña, pues, a la experiencia exterior, formada por cosas y acontecimientos fuera de nosotros, y a la experiencia interior, que es un retorno a sí mismo, la vuelta a la propia alma. Conforme con esta división, la imaginación desempeña un papel importante en el proceso ternario místico condicionado por la tradición del Pseudo-Dionisio Areopagita, en el cual el hombre debe dirigirse hacia lo exterior (teología simbólica) y lo interior (el conocimiento racional de las teologías afirmativa y negativa) hasta conseguir una pérdida del propio 'yo' en la experiencia de lo que está encima de él: en el arrebato sobrenatural de la teología mística (Walerich, 2013: 65).

\section{Teología simbólica}

En la primera etapa la imaginación es entendida en el sentido que le otorgó Platón, como imagen, resultado de la percepción sensorial, de la $\alpha \dot{\alpha} \iota \sigma \eta \eta \iota \varsigma^{1}$. Sin embargo, no tiene carácter superficial inherente a la phantasia platónica entendida como oposición frente al conocimiento que se dirige hacia la verdadera y eterna realidad de las ideas, las cuales no son, como escribe Platón (1992) en el Timeo, «perceptibles de manera sensible $(\dot{\alpha} \nu \alpha i ́ \sigma \theta \eta \tau \alpha)$ por nosotros, sino sólo captables por medio de la inteligencia $(\nu 0 u \mu \epsilon \nu) \gg(51 \mathrm{D})^{2}$. A diferencia de ello, en la primera etapa del proceso místico la imaginación se relaciona con «lo profundo», con lo espiritual.

Plotino (205-270), por ejemplo, cuando niega la necesidad de las imaginaciones, rechaza lo literal y lo superficial de los productos de imaginación que llegan a ser el objetivo y no el medio con ayuda del cual el pensamiento humano asciende hacia el Uno. Generalmente Plotino postula rechazar una actitud corriente y cotidiana para con la realidad. El conocimiento del Uno no se puede reducir a las imaginaciones subordinadas a la corporal y baja naturaleza del alma que se dirige a la sensualidad. En toda percepción hay que «despertar» en sí, «como cerrando los

1 Platón empleando el verbo $\pi \eta \alpha \iota \theta \alpha \nu o \mu \alpha \iota$ ( $\pi \eta \alpha \iota v \varepsilon \sigma \tau \eta \alpha \iota)$ se refiere a lo que aparece

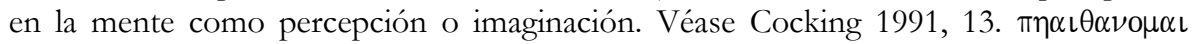

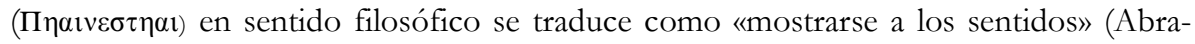
mowiczówna, 1965: 490).

2 Los términos griegos proceden de Perseus Collection. Greek and Roman Materials,

http://www.perseus.tufts.edu/hopper/collection?collection=Perseus:collection:GrecoRoman\&redirect $=$ true\#text1 [acceso: 12.2014 ]. 
ojos», «la vista interior», «la que todos tienen pero pocos usan» (Plotino, 1992: I 6.8-9). El que ve «bellezas corpóreas» debe ser consciente de que éstas sólo son imágenes, rastros y sombras de la belleza real, porque el

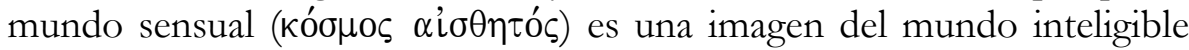

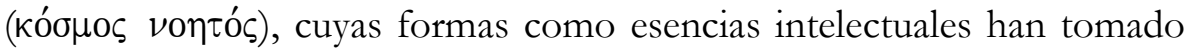
la forma espacial en las imágenes (Plotino, 1992: I 6.8-9; Cocking, 1991: 91).

El Pseudo-Dionisio Areopagita (s. V/VI) relaciona esta hipótesis con la idea expresada en el Libro del Génesis de que Dios creó al hombre a su imagen y semejanza (Gen 1,27), que el Pseudo-Dionisio refiere a toda la creación. Como escribe en el tratado De los nombres divinos, la criatura contiene el vestigio de la semejanza divina (Dionisio Areopagita, 2003a: IX \ 6). Inspirándose en la teología plotiniana de emanación y en la metáfora de luz, procedente del Nuevo Testamento desarrolla su teoría de teología simbólica que trata del carácter imaginario de la realidad y del habla humanas y la lleva hasta sus lejanas consecuencias. Dios emana rayos que alejándose de él como fuente de luz pierden la perfección divina, pero no en total. Así se crea la jerarquía de los seres que contiene «ciertas imágenes y semejanzas» de las formas divinas (Dionisio Areopagita, 2003a: VII \3; Ränsch, 1996: 77). De esta manera, dedicándose al análisis de la formación simbólica del lenguaje bíblico el Pseudo-Dionisio llega a la conclusión de que incluso en lo extraño de algunas imágenes que atribuyen a Dios adornos femeninos, armaduras de bárbaros, maldiciones, ira y envidia se encubre una hermosura que uno debe ser capaz de percibir. Es así, porque hasta los más bajos objetos materiales, como fuego, agua, piedra, animal, gusano han tomado el ser de la belleza superior y llevan en sí el rastro de la belleza (Dionisio Areopagita, 2003e: IX \ 1; 2003b: II \ 12). Por eso se puede hacer de ellos imágenes de Dios y de los espíritus puros. Sólo a través de esas imágenes sensuales y materiales el ser humano, que pertenece a la así denominada jerarquía eclesiástica subordinada a los sentidos, puede elevarse hacia lo invisible (Dionisio Areopagita, 2003c: I \9). Sin embargo, el puro conocimiento espiritual, propio de la naturaleza angélica que no necesita elevarse por medio de las cosas captables por los sentidos (Dionisio Areopagita, 2003c: I S 8), puede caracterizar también al que se libera de toda la imaginería infantil acerca de los símbolos sagrados y en vez de entender las imágenes simbólicas de la Escritura en modo literal empieza a percibirlas en una contemplación simple e interior (Dionisio Areopagita, 2003e: IX \1). De esta manera, el Pseudo-Dionisio al describir la inferior teología simbólica como una percepción contemplativa de la imagen que introduce al ser humano en los misterios divinos y es inefable, al mismo tiempo lleva una 
analogía con la superior teología mística. El conocimiento a través de las imágenes ofrece un prenuncio del conocimiento que se realiza en la tiniebla total y de ahí que resulte secreto e imposible de reflejar por medio del lenguaje. Esto se relaciona con la tradicionalmente aceptada por el Pseudo-Dionisio teoría de la división del alma en la esfera sensual y espiritual que colaboran consigo. El pensamiento en la esfera sensual que es susceptible a las sensaciones, al percibir una imagen extraña y enigmática, trasciende su capa sensual y en la esfera espiritual contempla lo que está oculto detrás de ella (Dionisio Areopagita, 2003e: IX \1). Así surge el conocimiento simbólico y la diferencia entre éste y el conocimiento místico consiste en que el último se realiza sin mediación de la percepción sensorial.

En relación con el Pseudo-Dionisio, Juan Damasceno (645-739) atribuye a las imágenes dibujadas la misma función que ése otorga a los símbolos bíblicos y al mundo sensual; las imágenes mediante lo corpóreo y accesible para los sentidos nos llevan a la contemplación del mundo divino y suprasensual: «Como estamos compuestos de una doble sustancia, alma y cuerpo,... es imposible que nosotros, lejos de las cosas corporales, alcancemos las espirituales... Así, mediante la contemplación cor-

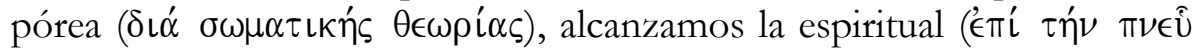
$\mu \alpha \tau \iota \kappa \eta \nu ~ \theta \epsilon \omega \rho i ́ \alpha \nu) »($ Tatarkiewicz, 1962: 57; Tatarkiewicz, 2007: 49). Al mismo tiempo admite que las cosas visibles representan las invisibles y carentes de figura refiriéndose a conjeturas difusas. Es así, porque la imagen ( $\epsilon \dot{i} \kappa \omega \nu)$ como una semejanza (ó $\left.\mu \hat{i}^{\omega} \omega \mu \alpha\right)$ que reproduce el proto-

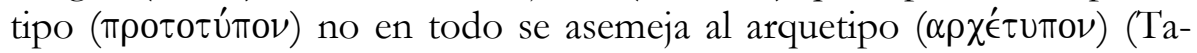
tarkiewicz, 1962: 56). Sin esta propiedad la imagen dejaría de ser una imagen.

En la filosofía occidental de Edad Media el convencimiento de la fuerza contemplativa de las imaginaciones en el proceso místico perdura entre los teólogos y místicos inspirados en el pensamiento del PseudoDionisio. Juan Escoto Erígena (s. IX), el traductor de su obra, subraya el carácter admirable e inefable de la belleza que deja de ser invisible como revelación de Dios en toda criatura visible e invisible, como teofanía. Las formas visibles son imaginaciones (imaginationes) de la belleza invisible, a través de las cuales Dios encamina a las almas humanas hacia la pura verdad (Tatarkiewicz, 1962: 124; Escoto Eriúgena, 2000: I 25). Este proceso es interminable así como son interminables las mismas teofanías, cuya forma y sutileza dependen del grado de la iluminación, purificación y perfección de la naturaleza humana por la gracia (Escoto Eriúgena, 2005a: 157; 2000: I 32). El Verbo está encarnado en las formas y composiciones de las cosas visibles que lo anuncian manifestándonos su belleza, 
y también en la letra de la Escritura que contiene sus misterios (Escoto Eriúgena, 2000: I 29). La luz eterna «en dos maneras se presenta al mundo: mediante la Escritura y mediante la criatura» (Escoto Eriúgena, 2000: 53) Leyendo la letra e investigando la criatura se puede ascender al espíritu de la letra y a las causas de la criatura. Solo de esta manera los que viven corpóreamente ascenderán a las alturas de las cosas espirituales (Escoto Eriúgena, 2000: VI 2, VI 3). Sin embargo, «hay una gran distancia entre la letra y el espíritu, entre la figura y la verdad, entre la sombra y el cuerpo» (Escoto Eriúgena, 2000: III 5) ${ }^{3}$. El que busca y encuentra teofanías se acerca cada vez más a la verdad, pero nunca la alcanzará, pues conocer al que es infinito se realiza de manera infinita incluso en las mentes más puras (Escoto Eriúgena, 2000: I 32).

Son los tempranos místicos del convento de San Víctor, que tematizan expresamente la relación entre la contemplación y la imaginación. Aparte de la filosofía del Pseudo-Dionisio, inspiran y justifican sus teorías las palabras de san Pablo de la Epístola a los Romanos (1, 20). «Porque lo invisible de Dios, desde la creación del mundo, se deja ver a la inteligencia a través de sus obras» (Cocking, 1991: 145-148).

En la teoría de Hugo de San Víctor (1096-1141), comentarista del Pseudo-Dionisio, la imaginación no trasciende el carácter sensual y exterior de la realidad circundante. Pues, si la poseen también algunos animales que carecen de la razón ${ }^{4}$, es más cercana a la sensualidad y no puede pertenecer a la parte espiritual (racional) del alma, aunque desempeña el papel de mediadora entre lo sensual y lo espiritual. Por eso san Hugo no atribuye la percepción de la dimensión simbólica y trascendental del mundo a la imaginación sino a la contemplación perteneciente a la intelligentia como la parte superior del alma. La contemplación se refiere a las cosas visibles que son esparcidas temporal y espacialmente y por tanto son perceptibles de manera sensual. Es capaz de abarcarlo todo con la clara vista, tiene pues carácter intuitivo (Tatarkiewicz, 1962: 233). El alumno de Hugo, Ricardo de san Víctor (m. 1173), define la contemplación como un conocimiento que se basa en la inteligencia, se realiza sin esfuerzo y es lleno de placer y exaltación (Dilger, 1971: 146). Pero en Benjamin Maior desarrolla una teoría de la contemplación en el proceso místico incluyendo en ella también el concepto de imaginación. De entre los seis tipos de la contemplación Ricardo atribuye a la imaginación la capacidad de participar en los tres inferiores, de los cuales el primero se relaciona con la teología simbólica. Como dice san Ricardo, la contem-

\footnotetext{
3 «Magna distantia est inter litteram et spiritum, inter figuram et veritatem, inter umbram et corpus» (Escoto Eriúgena, 1849: 320B).

$4 \quad \mathrm{Y}$ en los cuales la imaginación no trasciende la imagen de la percepción.
} 
plación en la imaginación y a través de la imaginación (in imaginatione et secundum solam imaginationem) es cuando percibimos las imágenes de las cosas visibles y «con admiración veneramos» el poder, la sabiduría y la generosidad del Ser supremo y creador. Esta contemplación la caracteriza sobre todo el factor emotivo expresado en la admiratio que se puede definir como admiración asombrada. Se refiere no sólo a la naturaleza, sino a todas las obras humanas, puesto que las obras del que reconoce en las cosas de este mundo el vestigio de Dios, también llevan en sí la sombra del invisible (Tatarkiewicz, 1962: 234; Dilger, 1971: 30; Walerich, 2013: 45).

Para san Buenaventura (1221-1274), las cosas exteriores entran en nuestra alma «por sus semejanzas» por las puertas de los cinco sentidos en las etapas de aprehensión cognoscitiva (apprehensio), delectación del conocimiento (oblectatio) y juicio de las cosas sensibles (diiudicatio). En estas etapas conviene considerar y conocer a Dios en todas las criaturas, bendecirle y amarle. Pues, los objetos que engendran sus semejanzas, también fueron engendrados como semejanzas de su fontal principio y objeto; todas las delectaciones nos llevan de la mano a buscar la delectación fontal y verdadera que está en solo Dios; y el juicio que consiste en abstraer del lugar, tiempo y mutabilidad, de la dimensión, sucesión y mudanza, toma en consideración lo eterno (lo inmutable, incircunscriptible e interminable) demostrando así que Dios es la razón de todas las cosas, la regla infalible y la ley (Buenaventura, 2006: cap. 2.2, 2.4, 2.7-2.9, 2.13). Una aprehensión como esta del mundo circundante equivale a la cointuición de Dios ${ }^{5}$. Puesto que todo el mundo material es un espejo, todas las criaturas son sombras, resonancias y pintura que guían el alma del hombre contemplativo y sabio a Dios. Es así porque Dios es el origen, el ejemplar y el fin de las cosas creadas, y todo efecto es signo de la causa, toda copia es signo del ejemplar, todo camino es signo del fin al que conduce (Buenaventura, 2006: cap. 2.11, 2.12).

En los autores mencionados arriba, el contacto con el mundo visible, en que toma parte la imaginación entendida en el sentido platónico, hace necesario activar la vista interior (Plotino), la percepción contemplativa (El Pseudo-Dionisio), la contemplación espiritual (Juan Damasceno), el reconocimiento de la propiedad teofánica (Eriúgena), la contemplación en la imaginación (Ricardo de san Victor) y la cointuición (Buenaventura). Introducen, pues, en el contexto de imaginación entendida como resultado de la percepción sensorial un momento de la comprensión

\footnotetext{
5 «Los dos grados primeros (...) son no solamente vestigios, simulacros y espectáculos puestos ante nosotros para cointuir a Dios (ad contuendum Deum), sino también signos que, de modo divino, se nos han dado» (Buenaventura, 2006: 2.11).
} 
intuitiva que supera lo exterior y superficial sin transformarse todavía en el entendimiento racional. Esta diferencia la expresa el filósofo renacentista, Marsilio Ficino (1433-1499), para quien la fantasía es una facultad intermedia entre la imaginatio y el intellectus. La imaginatio solo ve lo exterior y superficial, mientras que la phantasia «súbitamente» percibe lo sustancial, por ejemplo lo bello, lo bueno, la amistad. El primer acto del intelecto es cercano a la operación espontánea de la fantasía: en cuanto la fantasía pinte la imagen de Platón, el intelecto también, con su fuerza natural, «súbitamente», «sin cualesquiera consideraciones discursivas» crea en el pensamiento $(\varepsilon \chi \xi o \gamma \iota \tau \alpha \tau)$ la esencia y la idea del ser humano. Gracias a la operación de la fantasía que representa la belleza y la bondad relacionadas con una persona concreta, el intelecto encamina el pensamiento hacia la esencia y el concepto general de la belleza y de la bondad (Ficino, 2006: VIII 1). Así, en el concepto de Ficino la fantasía se asemeja más al intellectus (o mens) ${ }^{6}$ que a la imaginatio por tener los dos «un sentido de lo sustancial» que condiciona sus operaciones, aunque este sentido tiene un mayor alcance en el pensamiento, es más seguro, intenso, penetrante e indivisible que el sentido en la fantasía (Ficino, 1993: 102-105). El pensamiento y la fantasía (mens et phantasia) son, pues, los «ojos gemelos» de un alma. Colaboran consigo y ven lo mismo, pero de manera distinta, propia de cada uno de ellos. Su semejanza fraterna hace que, cuando la fantasía forma sus imágenes (species), las forme también el pensamiento (mens) y cuando el pensamiento encuentra sus imágenes, estas se reflejen en la fantasía (Ficino, 2006: XI 3; XII 2; XV 9). De esta manera intercambian sus propiedades.

Los autores mencionados distinguen, pues, en la imaginación un momento de intuición, cuando la realidad verdadera se nos muestra como algo maravilloso y momentáneo en el sentimiento. Esa experiencia se expresa en el concepto de la admiratio, de una admiración en que se efectúa el olvido de sí mismo, la supresión de la diferencia que separa el sujeto y objeto, que es característica para el asombro. De este modo, la teología simbólica como etapa inicial del proceso místico se convierte de una experiencia exterior y sensorial en una vivencia interior y directa que uno hace en sí mismo. Esas vivencias singulares, intuitivas y maravillosas interrumpen el curso de la vida cotidiana. Aunque son actos momentáneos, resultan de una postura de vida, porque se llevan a cabo gracias a la consciencia de la imagen, según la cual todo el mundo circundante, como producto de Dios o como emanación del Uno y campo de los actos creativos del ser humano, lo entendemos como imagen de algo: de su creador y de la primera causa.

O la intelligentia, porque Ficino suele usar estos términos de manera sinónima. 


\section{Razonamiento discursivo}

La segunda etapa del proceso místico tradicionalmente se relaciona con el conocimiento racional atribuido al retorno a sí mismo, a la experiencia interior. Esta etapa tiene su equivalente en las teologías afirmativa y negativa del Pseudo-Dionisio como un conocimiento filosófico que emplea la demostración y es manifiesto, y se refiere a las cosas inteligibles (Dionisio Areopagita, 2003e: IX \ 1; Buenaventura, 2006: cap. 1.7). El Pseudo-Dionisio las presenta en el tratado De los nombres divinos en el que considera el significado de los conceptos inmateriales y captables para el entendimiento -Verbo, Espíritu, Esencia, Bondad, Luz, Belleza, Amor, Vida- aunque, como subraya, la divinidad se alza sobre todo ser, todo nombre y todo llamamiento (Dionisio Areopagita, 2003a). Conocemos los nombres divinos no por la inteligencia humana, sino, al igual que las imágenes, gracias a la inspiración otorgada por el Espíritu Santo a los autores de las Escrituras. Las caracteriza una semejanza con Dios. Al mismo tiempo resultan insuficientes, porque Dios sobrepasa lo todo. Por eso se escribe de él también por medio de atributos negativos, como invisible, incomprensible, infinito, que son más adecuados, porque desconocemos su ser sobresencial e inefable (Dionisio Areopagita, 2003b: II $\int 5$, II $\int 6$, II $\left.\int 7\right)$. De ahí que las teologías afirmativa y negativa se condicionen mutuamente y no puedan existir una sin la otra, porque las semejanzas de la primera se complementan con las desemejanzas de la segunda y así crean la totalidad del conocimiento racional (Walerich, 2013: 32).

En general, se puede decir que en la tradición mística, la etapa intermedia atribuida a la experiencia interior la constituye principalmente el razonamiento discursivo. La imaginación, en este caso, adopta el papel establecido por la tradición aristotélica de suministrar a la razón las imágenes de las percepciones sensoriales, de las cuales la razón deduce los conceptos (Aristóteles, 1988: 427b-429a, 431b-433b; Volonté, 1997: 2433). Por ejemplo, para Hugo de San Víctor la imaginación desempeña el papel de mediadora entre lo sensual y lo espiritual. La sustancia de la razón (ratio) es un espíritu inmaterial o la luz, y la imaginación, como imagen de un cuerpo, es una sombra que se eleva a la luz: desensualiza y espiritualiza, o sea abstrae parcialmente las imágenes materiales de la percepción (phantasmata) y las introduce en la razón que las somete al juicio y se sirve de ellas durante el pensamiento (cogitatio). Esa capacidad la distingue de la imaginación bestial que se detiene en sola imagen sensual (phantasma) (Hamesse, 1988: 168s.; Dilger, 1971: 71; Cocking, 1991: 146). Sin embargo, es santo Tomás de Aquino ( $\approx 1225-1274)$ quien lleva esta tradición hasta sus últimas consecuencias. Como señala Umberto Eco, Tomás de Aquino pone fin a la metáfora universal con su opinión 
de que es el ser humano el que crea las metáforas, o sea también las analogías entre el mundo humano y divino. De esta manera excluye de la teología la esfera relacionada con el simbolismo que entiende el mundo como libro exterior escrito por Dios (Ränsch, 1996: 84s). Por supuesto, Tomás de Aquino no niega que las cosas de este mundo sean vestigios de presencia y actividad divinas. En el vestigio la causa se revela de modo general e indefinido. El vestigio manifiesta únicamente el solo hecho de estar causado y no la misma causa: no su esencia (forma) (Pöltner, 1991: $188)^{7}$. El ser humano percibe, por tanto, las criaturas únicamente como vestigios de la actividad divina, no contempla en ellas al Dios mismo, sino la belleza de éstas: la belleza empírica (Tatarkiewicz, 1962: 287s). Así la imaginación pierde el papel consolidado por el Pseudo-Dionisio en la experiencia metafísica del mundo. Tomas de Aquino normalmente manifiesta su interés en la imaginación por el papel que cumple en el proceso de entendimiento. Nibil sine phantasmate intelligit anima, dice en Suma teológica aludiendo a Aristóteles (Aquino, 2001: I 84.7). Conocemos las realidades incorpóreas a través de su relación con lo sensual, cuyas imágenes poseemos. Sólo en el camino de la reflexión podemos conocer la verdad, y un fundamento de la reflexión son imágenes (phantasmata). Todos pueden experimentar por sí mismos que cuando intentan entender algo se crean ciertas imágenes como ejemplos en los cuales pueden ver lo que quieren entender (Aquino, 2001: I 84.7). Así, la razón discursiva a través de las cosas visibles consigue el conocimiento de lo invisible. Mientras que los ángeles por naturaleza poseen el perfecto conocimiento de la verdad inteligible, la aprehenden directamente y sin proceso analítico, los hombres acceden a la verdad inteligible pasando de un concepto a otro, por eso son llamados racionales. El raciocinar con respecto al entender es como el moverse con respecto al reposar o como el adquirir con respecto al poseer. No obstante, el ser humano, si bien imperfectamente, llega al conocimiento de la verdad inteligible, conocida por los ángeles, y del mismo Dios que - dice Tomás en relación al Pseudo-Dionisio- conocemos como causa y por vía de eminencia y negación (Aquino, 2001: I 79.8, I 84.7). De esta manera Tomás de Aquino, de acuerdo con la tradición de Aristóteles y san Agustín, invariablemente atribuye la imaginación mejor a la razón discursiva y elimina del proceso místico la teología simbólica.

El mismo concepto de la forma Tomás, en este caso, lo adoptó de Aristóteles en el que la forma significa esencia de una cosa, aquí: la esencia del Dios mismo. 


\section{Ejercicio espiritual}

Por otra parte, en la segunda etapa del proceso místico la imaginación desempeña el papel del ejercicio espiritual que conduce al fin definido: a la iluminación o visión espirituales. Ya en Plotino es un método, en que se realiza el pensamiento más intenso, cuyo objetivo consiste en captar la verdad que trasciende toda percepción sensorial. Plotino explica por ejemplo, cómo imaginándose un espacio cósmico se puede conseguir de repente la visión del cosmos noético ${ }^{8}$ :

Reflexionemos sobre este mundo sensible, en el que cada una de sus partes permanece tal cual es y sin mezcla alguna, pero coincidentes todas en una unidad en la medida en que esto es posible, de tal modo que la aparición de una cualquiera de ellas, como por ejemplo la esfera exterior del cielo, se ofrece ligada inmediatamente a la imagen [phantasia] del sol y, a la vez, a la de los demás astros, viéndose así la tierra, el mar y todos los animales como en una esfera transparente en la que podrían contemplarse realmente todas las cosas. Tened, pues, en vuestro espíritu la imagen [phantasia] luminosa de una esfera, que contiene en sí misma todas las cosas, esto es, tanto les seres en movimiento como los seres en reposo, tanto los seres que no están en movimiento como los que no están en reposo. Y, con esta imagen en vosotros mismos, prescindid de su masa, e incluso de su extensión y de la materia contenida en la imagen [phantasma]. No imaginéis tampoco otra esfera de masa mucho más pequeña, invocad, si acaso, al dios que ha producido la esfera de la que tenéis la imagen [phantasma] y suplicadle que se acerque hasta vosotros (Plotino, 1975: V 8.9).

Así pues, en Plotino la phantasia de carácter espacial llega a ser un factor importante en el proceso que se dirige hacia la contemplación del Uno eterno e inmudable. Eso se relaciona con el concepto del retorno inteligible - del retorno del pensamiento- a su fuente originaria, con el movimiento 'hacia adentro' en el acto de una con-centración cada vez

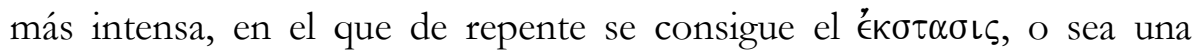
salida del 'yo' o, más bien, la liberación del 'yo' superficial y la experiencia del 'yo' profundo (Albert, 2002: 51). El pensamiento se dirige así de la multitud a una causa intuida por la consciencia (Beierwaltes, 2003: 16). Hay que subrayar que en ese proceso phantasiai o phantasmata tienen cualidades excepcionales, porque resultan de un esfuerzo consciente y de una voluntad independiente, por tanto no son imaginaciones típicas que se crean pasiva y maquinalmente bajo la influencia de las sensaciones

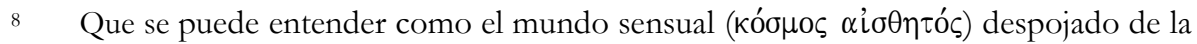
materialidad -o sea también del tiempo y espacio- que encubre las formas eternas. 
corporales, por ejemplo a causa del hambre y de la sed (Plotino, 1967: VI 8.3).

También en la autobiografía de san Agustín aparecen momentos que indican una participación preparatoria de la imaginación en conseguir una visión, cuando el pensamiento recorre las imágenes en el palacio de la memoria como el sinónimo del 'yo' que constituye un fundamento insondable de la consciencia humana. El ejercicio consiste en una concentración cada vez más intensa del pensamiento que recorre las imágenes de las percepciones sensuales, las imágenes de las sensaciones espirituales (emociones) y las imágenes inteligibles (números e ideas) en la búsqueda de la imagen de Dios conocida antaño, que se oculta en una parte de las profundidades del alma (San Agustín, 1946: X \25, 27) ${ }^{9}$. Por otra parte, incluso sus ilusiones y apariencias, cuyo objetivo es crearse la imagen del Dios infinito, y que Agustín rechaza como abominables, se puede entender como un elemento del ejercicio espiritual, en el que no cuenta el mismo contenido literal de éstas, sino la intensidad, con la que el pensamiento las forma en la incesante búsqueda (San Agustín, 1946: VII $\left.\int 5,14\right)$ :

Pero después que Vos curasteis mis delirios e ignorancias y me hicisteis cerrar los ojos de mi entendimiento para que no mirase ni atendiese a las quimeras vanas que interiormente veía, cesé algún tiempo de imaginar fantásticas ideas y se adormeció aquella mi locura. Al fin, desperté para pensar en Vos y vi que verdaderamente sois infinito, pero muy de otra suerte que yo me lo había figurado: esta vista o conocimiento no pertenecía a los ojos corporales (San Agustín, 1946: VII \14).

Ricardo de San Víctor atribuye al tercer tipo de contemplación: en la razón a través de la imaginación (in ratione secundum imaginatione), la capacidad de conducir a la iluminación. En esta contemplación, según san Ricardo, la imaginación representa a nuestra razón las formas de cosas visibles y nos prepara a través de la imagen a profundizar en lo invisible. La imaginación nos conduce en cierto modo adonde nunca llegaríamos si tomáramos por punto de partida la sola razón. En esta etapa tratamos toda la realidad circundante, también las obras humanas, como símbolo (similitudo) de lo invisible. San Ricardo define la diferencia entre lo visible y lo invisible como dissimilis similitudo. La relación de semejanza entre ellos es más intensa, porque es más cercana y más profunda que la que sucede entre los cuerpos y se refiere solo a su aspecto exterior. El proceso de conocer esta semejanza empieza por definir precisamente las pro-

Véase también la característica de la imagen en Watson (1986: 45).

VERITAS, No $^{\circ} 3$ (Septiembre 2015) 
piedades de las cosas visibles, con el fin de crear en la mente imágenes generales sobre la base de las analogías que hay entre ellas, y luego someter estas imágenes a la interpretación simbólica apoyándose en la causa divina que se manifiesta ellas. Su coronación es illuminatio, en la que esas imágenes y las estructuras categoriales quedan trascendidas y recibimos el conocimiento de la idea divina que las originó. En esta etapa de la contemplación el hombre exterior se convierte en el hombre interior, espiritual. San Ricardo, aludiendo al Pseudo-Dionisio, subraya que esta transformación se lleva a cabo gracias a imaginationis manuductio, gracias a la imaginación que nos guía de mano. Ricardo insiste en que el conocimiento contemplativo así generado es alejado de las imaginaciones e imágenes de las cosas sensuales. De esta manera subraya su mayor disimilitud que similitud al invisible (Aris, 1996: 73-79; Walerich, 2013: 45s).

Para san Buenaventura la imaginación también es un método del ejercicio espiritual que caracteriza no tanto la intensidad de formar las mismas imaginaciones, sino la intensidad de la empatía con las imágenes verbales que muestran a Cristo. En el Lignum vitae, Buenaventura de manera plástica representa la historia de Jesús en forma de un árbol simbólico. Como escribe en el prólogo: «la imaginación ayuda a entender» (imaginatio iuvat intelligentiam), y anima a experimentar vivamente en el propio interior el sentimiento de la similitud con el Salvador, que surge, cuando con gratitud consideramos la labor, el dolor y el amor del Jesús crucificado (Buenaventura, 1898: 68). En este caso la facultad imaginativa no lleva a una visión o iluminación, sino a una identificación: al descubrimiento en sí mismo de una semejanza con Cristo.

El ejercicio espiritual consiste, pues, en una concentración cada vez más intensa del pensamiento o sentimiento. El principio de su funcionamiento se basa en el paso de lo extendido a lo concentrado: Como escribe el Pseudo Dionisio, cuanto más cerca estamos de Dios, tanto más concentrado se hace todo y cuanto más lejos, tanto más extendido. Por eso el puro conocimiento espiritual, propio de la jerarquía celeste a la cual pertenecen los ángeles y los santos, al contrario del conocimiento imaginario que a veces requiere muchas palabras, lo caracteriza la simplicidad y brevedad (Dionisio Areopagita, 2003d: III). Esta centración psíquica tiene su equivalente en el concepto de imagen

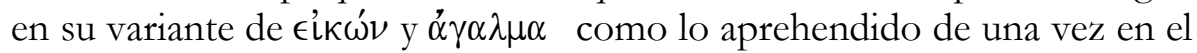
conjunto. Su oposición es $\gamma \rho \alpha \mu \mu \alpha \dot{\alpha}$ y $\epsilon \mathfrak{l} \delta \omega \lambda \mathrm{\alpha} \nu$ que se desenvuelven en discursos y en proposiciones. Se basa, por tanto, en la diferencia entre lo desenvuelto y lo conjunto:

No hemos de pensar, pues, que en el mundo inteligible los dioses y los seres bienaventurados contemplan proposiciones; ya que todas las fórmulas 
de ese mundo no son otra cosa que bellas imágenes ( $\alpha \dot{\alpha} \alpha \dot{\lambda} \lambda \mu \alpha \tau \alpha)$, como se representan las que hay en el alma del hombre, y no en verdad diseños de imágenes $\left(\gamma^{\prime} \gamma \rho \alpha \mu \mu \in \mathcal{\nu} \alpha\right)$ sino imágenes reales. De ahí que dijesen los antiguos que las ideas son seres y sustancias.

A esto llegaron, en mi opinión, los sabios de Egipto, bien medio de una ciencia exacta, bien de una manera natural. $\mathrm{Y}$ así, respecto a las cosas que quieren mostrar con sabiduría, no se sirven de tipos de letras que se desenvuelven en discursos y en proposiciones, representando a la vez sonidos y palabras, sino que dibujan imágenes ( $\alpha \gamma \alpha \dot{\alpha} \lambda \mu \alpha \tau \alpha)$, cada una de las cuales se refiere a una cosa distinta. Estas imágenes son grabadas en los templos para dar a conocer el detalle de cada cosa, modo que cada uno de los signos constituye una ciencia y una sabiduría, una cosa aprehendida de una vez y no algo parecido a un pensamiento o a una deliberación. De esta sabiduría conjunta proviene a continuación una imagen ( $\epsilon \hat{l} \delta \omega \lambda \mathrm{o \nu})$ que se desenvuelve en otra cosa y que aparece formulada en un decurso de pensamiento (Plotino, 1975: V 8.5, 8.6).

Este método contemplativo lo expresa también el ícono bizantino, en que el rostro, sobre todo los ojos constituyen el centro del cuadro, para que el espectador pueda concentrarse en ellos y quedarse como inmóvil (Tatarkiewicz, 1962: 44-48).

\section{Teología mística}

Por lo tanto, en las dos etapas del proceso místico las imaginaciones son un medium que bien sirve para manifestar una imagen del Absoluto, bien como ejercicio espiritual que consiste en la intensidad de formar las imaginaciones o en la intensidad de la empatía con las imaginaciones. Constituyen, pues, una oposición frente a la «concupiscencia de los ojos» (San Agustín, 1946: X \ 35) que atribuye a los elementos de la realidad circundante el significado y la función relacionados con objetivos personales e interesados y así hace de éstos «falsas imaginaciones»y «sombras» (Eriúgena, 2005b: 173, 181). Introducen, además, una concentración consciente y conducen hacia una supresión gradual de la consciencia de sí mismo, la supresión que tiene culminación en la iluminación o identificación. De esta manera preparan al hombre a la final vivencia extática, conforme al pensamiento de Lavelle, según el cual la pura experiencia del ser supone una inocencia, la mente libre de todo interés propio e incluso de toda inquietud interior (Albert, 2002: 35). En estas etapas la imaginación es libre de toda connotación con lo fantástico y con la ensoñación. Lo fantástico lo elimina la consciencia presente en la teología simbólica de que las imágenes de la realidad y de la imaginación son representantes de otras cosas y no ilusiones o componentes 
autónomos de la pura fantasía ${ }^{10}$. En cambio, la finalidad del ejercicio espiritual hace imposible toda ensoñación. Es así porque el ejercicio espiritual no se detiene en las imaginaciones mismas, no consiste en pensamientos maquinales, sino que es un método que intensifica el proceso pensativo (Walerich, 2013: 66s).

En este sentido las teologías simbólica e intelectual son una sombra e imagen que preparan para ver la luz. La experiencia mística como rayo de tiniebla es inefable. Pero resuena en la imagen entendida ética y ontológicamente. $\mathrm{Al}$ respecto, conforme a la tradición platónica y cristiana el ser humano y su vida son una imagen de la virtud, del Uno o

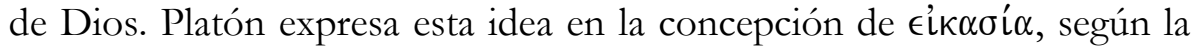
cual el que verdaderamente ha conocido la virtud llega a ser su imagen.

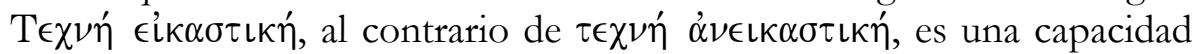
de producir semejanzas, que no se interesa por el mismo fenómeno sensual sino por su esencia, es una imitación erudita, porque su fundamento es la ciencia (Platón, 1988: 267 B-E) $)^{11}$. Para Plotino, todo el proceso místico es al mismo tiempo una formación y un descubrimiento sucesivos de la imagen del Uno. Durante la experiencia mística el ser humano parte de sí mismo como imagen y se remonta hasta el modelo

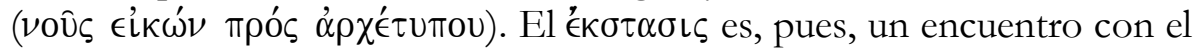

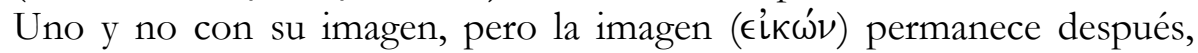
unida con el recuerdo de la experiencia, aunque Plotino no define claramente en qué consiste (Plotino, 1998: VI 9.11). En la convicción de los filósofos cristianos, el hombre restituye en sí la imagen de Dios, según la cual fue creado, si se permite dirigir por la voluntad divina, o sea se aparta del pecado y consigue un conocimiento de Dios (San Agustín, 1946: XIII \ 21). Entonces, como su espejo, llega a ser capaz de entender intuitivamente y luego de llevar a cabo la exégesis del nivel simbólico de la Escritura. En este sentido se puede interpretar las palabras de Eriúgena, según el que los doctores de la Iglesia recogen en uno los signos (sentidos) de las Escrituras y luego los distribuyen a los que son capaces de entenderlos (Escoto Eriúgena, 2000: VI 4). Pero, efectivamente, es Tomás de Aquino el que confiere a la imaginación humana y a las imágenes formadas por ésta la capacidad de expresar la experiencia mística por medio del lenguaje, si bien ya en el PseudoDionisio el término túmos y en Plotino la concepción de phantasia

10 La ilusión la entiendo aquí en el sentido de Platón y Husserl: como una realidad sensorial y aparente, una oposición de la realidad verdadera, y como una alucinación que se produce, cuando percibimos algo y creemos que existe de verdad. Volonté, 1997: $184 \mathrm{~s}$.

11 Sobre el concepto de la imagen en el Sofista, véase Camassa (1988: 27); Ambuel (2007). 


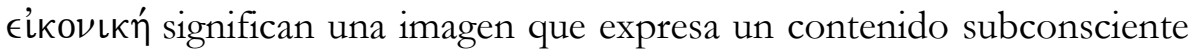
o sobrenatural de pensamiento (Dionisio Areopagita, 2003e: IX \1; Plotino, 1965: III 6.18).

En el capítulo de la Suma I 12.9 dedicado a la visión de san Pablo, Tomás de Aquino toma en consideración la capacidad humana de traducir en imágenes (similitudines) las imágenes (similitudines) inteligibles que están en la esencia de Dios y se refieren a todas las cosas ${ }^{12}$. La mente, gracias a la unión con la esencia divina, se asemeja (assimilatur) a las imágenes que contempla en ella y las conserva en sí también después de acabar la visión. Por eso Tomás supone que san Pablo puede formar en sí semejanzas de imágenes inteligibles guardadas en la memoria, aunque sean distintas de las imágenes percibidas durante la visión. Tomás de Aquino no indica claramente, cuál potencia del alma lleva a cabo esta transformación. Menciona, sin embargo, la imaginación y el entendimiento como las potencias cognoscitivas que sobre la base de las imágenes anteriormente concebidas (ex speciebus primo conceptis) pueden formar otras nuevas. Por ejemplo, la imaginación partiendo de las imágenes del monte y del oro forma la imagen del monte de oro (speciem montis auret ${ }^{13}$, y el entendimiento (intellectus), a base del género y de la diferencia que existe entre imágenes, forma la razón de la especie (specie) (Aquino, 2001: I 12.9) ${ }^{14}$. Pero san Pablo, quien dijo de sí que «oyó palabras desconocidas que ningún hombre puede pronunciar» (Aquino, I 12.9) -et audivit arcana verba, quae non licet homini loqui (2 Co 12, 4)- no

12 En este caso «todas las imágenes» contienen también todas las imágenes (especies) inteligibles creadas, las cuales santo Tomás menciona en la parte II-II 175.4 de la Suma, o sea las imágenes que ya están en el alma sin imagen o las imágenes abstraídas por el entendimiento de las imágenes de las cosas (Aquino, 2001: I 12.11); contienen también las imágenes de las cosas potenciales, o sea de las cosas que todavía no están en acto. En este párrafo, en las paráfrasis de las formulaciones de Tomás de Aquino empleo el concepto de la imagen que aparece en él en varios contextos y significados, es decir: imago; similitudo; species; metaphorice (figurate) dicere; repraesentatio; phntasma; forma (Pöltner, 1991).

13 En santo Tomás species, al igual que imago y similitudo significa imagen en sus varias conotaciones. En este contexto species significa la forma y el aspecto exteriores. Species, a parte de este sentido corriente, significaba en la lógica el contenido conceptual y no sensorial de una cosa (Tatarkiewicz, 1962: 253).

14 Aquí species como especie significa, por una parte una oposición frente al género, como lo que es más general, y por otra, una oposición frente a los que es individual. Por ejemplo, ente el gusano y el ser humano no aparece ninguna relación imaginaria, aunque los dos se parecen con respecto al género, son seres vivos. Tampoco la semejanza respecto al color no justifica la relación imaginaria, porque no decide de algo por su esencia específico, característico para «la manera de ser» (para la especie). Por eso la especie (species) constituye una de las condiciones fundamentales para que pueda producirse la relación imaginaria (Pöltner, 1991: 179; Schütz, 1958). 
forma en sí las imágenes, como lo atestigua el versículo de la Epístola a los Corintios. Sin embargo, en este caso llama la atención el verbo que usa: non licet, que no significa que no sea capaz de expresar las «palabras secretas», sino la indignidad que resulta de la bajeza de las potencias cognoscitivas humanas frente al conocimiento divino. Es lícito hablar de lo que es secreto -explica santo Tomás en el Comentario a la Segunda Epistola a los Corintios- si el que lo expone y el que lo escucha son hombres espirituales. De esta manera interpreta las palabras de san Pablo: «hablamos de sabiduría entre los perfectos» (1 Co 2, 6). Tomás de Aquino tampoco dice explícitamente en qué consiste y a qué lleva la misma formación de nuevas imágenes, pero en base a sus declaraciones sobre las visiones proféticas y el funcionamiento del entendimiento humano se puede llevar una analogía. El ser humano que contempla la esencia divina, recibe un entendimiento temporal de las imágenes inteligibles de todas las cosas que existen en ella $^{15}$ y que corresponden tanto a las cosas creadas como a las potenciales, así que contienen solo una mínima fracción de las imágenes inteligibles que conoce. Estas imágenes están ordenadas adecuadamente y la contemplación de este orden durante la visión trae un conocimiento místico. De modo parecido, de la distinta colocación de letras se producen palabras nuevas y de la distinta disposición de imágenes (phantasmata) se producen en el entendimiento (intellectus) diversas imágenes inteligibles (species intelligibiles). Un proceso analógico tiene lugar en la visión profética caracterizada por el carácter sobrenatural de imágenes y por su entendimiento sobrenatural: en la revelación profética Dios ordena las imágenes (species imaginariae) recibidas de la experiencia sensual, para enseñar la verdad que quiere revelar. Cuando la visión de la esencia divina pasa, el ser humano no es capaz de recordar esa estructura, se conservan en él únicamente algunas imágenes inteligibles fragmentarias y desordenadas: letras parciales y dispersas de las palabras secretas. Le queda, pues, un intento de traducirlas en imágenes nuevas, formadas de las imágenes conocidas y de las que se han conservado en él después de la visión. Puesto que, el hombre, subraya santo Tomás, puede por sí mismo formar imágenes de toda clase, sin embargo, no puede ordenarlas de modo racional para expresar una verdad sobrenatural. Por consiguiente, san Pablo o cualquier otra persona que haya visto la esencia de Dios, puede formar en sí semejanzas de las imágenes existentes en ella, pero no puede ordenarlas racionalmente de tal modo que le permita entenderlas. Por tanto, la imaginación, su carácter innovador, creativo e intuitivo, resulta 15 Este carácter pasajero distingue su experiencia de la visión de bienaventurados en el
cielo, que es eterna. 
la potencia cognoscitiva, gracias a la cual, basándose en lo que nos es familiar y es captable sensorialmente, podemos transmitir las realidades que están ocultas ante nuestra sensual y racional manera del conocer, sometida a las categorías de tiempo y espacio. La experiencia de la esencia divina sobrepasa la visión profética, pero, como en la visión profética, la distinguen dos momentos principales: el conocimiento (cognitio) y su pronunciación (locutio) (Aquino, 2001: II-II 171.1; Walerich, 2013: 57s). En la visión profética el mensaje divino se expresa por medio de palabras-símbolos ${ }^{16}$ o por medio de imágenes sobrenaturales ${ }^{17}$. Pero, ¿cómo traducir al lenguaje la experiencia que por su naturaleza es inefable? Parece que esta pregunta acompaña a santo Tomas a lo largo de varios capítulos de su obra. Y en efecto, consigue poner solución a esta paradoja. Aunque sólo indirectamente, confiere a la imaginación humana la primacía sobre el entendimiento. De esta manera, gracias a relacionar las imágenes formadoras con la experiencia de san Pablo, el principal místico de la Iglesia, les confiere una significación inusual hasta entonces. Agustín la expresó como una gran fuerza formadora de imágenes:

Porque cuales eran las formas por las que solían andar mis ojos, tales eran las imágenes por las que marchaba mi espíritu. Ni veía que la misma facultad con que formaba yo tales imágenes (banc eandem intentionem qua illas ipsas imagines formaban) no era algo semejante, no obstante que no pudiera formarlas si no fuera alguna cosa grande (San Agustín, 1946: VII $₫ 1)^{18}$.

Ficino la formulará por medio de phantasia intellectualis e intellectus phantasticus (Ficino, 2006: XV 9). En el capítulo VIII de la Platonica Theologia dedicado a las operaciones del pensamiento, Ficino llama el pensamiento una fuerza maravillosa, que devuelve la multitud infinita al uno, y el uno a la multitud infinita o asciende hacia el uno infinito y desciende hacia la multitud infinita. Posee, así, no solo la capacidad de abstraer,

16 Por ejemplo David contemplaba la verdad divina en la visión intelectual: «Yo dije en mi arrebato: Todo hombre es mentiroso» (Sal 115,11); en la versión de Vulgata: «Ego dixi in excessu meo: omnis homo mendax» $(115,2)$ (Biblia Sacra juxta Vulgatam Clementinam, 2005). Véase Aquino (2001: II-II 175.3).

17 En el Profeta Isaías «El año de la muerte del rey Ozías vi al Señor sentado en un trono excelso y elevado, y sus haldas llenaban el templo» (Is 6, 1), véase Tomás de Aquino (2001: II-II 174.3; II-II 175.3). En la experiencia de Pedro: «Mientras se lo preparaban le sobrevino un éxtasis, y vio los cielos abiertos y que bajaba hacia la tierra una cosa así como un gran lienzo, atado por las cuatro puntas» (Hch 10, 10- 10, 11), véase Aquino (2001: II-II 173.3). En la experiencia de Juan: «Al instante caí en éxtasis. Vi que un trono estaba erigido en el cielo, y Uno sentado en el trono» (Ap 4, 2). Véase Aquino (2001: II-II 175.3).

18 La cita original en latín procede de San Agustín (1992). 
sino también la de transformar lo abstraído en formas e imágenes. Por lo tanto, cuando habla del pensamiento, toma en cuenta también la imaginación.

\section{REFERENCIAS}

-Abramowiczówna, Z. (1965). Stownik grecko-polski (Vol.4). Warszawa: PWN.

-Albert, K. (2002). Wprowadzenie do filozoficznej mistyki (J. Marzęcki, Trad. pol). Kęty: Antyk.

-Ambuel, D. (2007). Image and paradigm in Plato's Sophist. Las Vegas-ZurichAtens: Parmenides Publishing.

-Aquino, T. de (2001). Suma teológica. Madrid: BAC

-Aquino, T. de (2012). S. Thomae de Aquino Opera Omnia (E. Alarcón, Ed.). Recuperado de http://www.corpusthomisticum.org/iopera.html

-Aris, M.A. (1996). Contemplatio. Philosophische Studien zum Traktat Benjamin Maior des Richard von St. Victor. Frankfurt am Main: Verlag Josef Knecht.

-Aristóteles (1988). O duszyy (Segunda edición). (P. Siwek, Trad.pol). Warszawa: PWN.

-Beierwaltes, W. (2003). Platonizm w chrzésiciaństwie (P. Domański, Trad. pol.). Kęty: Antyk.

-Biblia Sacra juxta Vulgatam Clementinam (2005). Recuperado de http://www.wilbourhall.org/pdfs/vulgate.pdf

-Buenaventura (1984). Drzewo życia (Lignum vitae). En Buenaventura Pisma ascetyczno-mistyczne. (K. Żuchowski, Trad. pol., pp. 259-285). Warszawa: Akademia Teologii Katolickiej.

-Buenaventura (2006). Itinerario de la mente a Dios. Recuperado de http://www.documentacatholicaomnia.eu/04z/z_12211274_Bonaventur a_Itinerarium_Mentis_in_Deum_ES.pdf.html

-Buenaventura (1898). Lignum vitae. En Buenaventura, Opera Omnia (Vol. 8). Recuperado de http://www.documentacatholicaomnia.eu/20vs/221_Bonaventura/12211 274,_Bonaventura,_Doctoris_Seraphici_Opera_Omnia_\%28Quaracchi\%2 9_Vol_08,_LT.pdf

-Camassa, G. (1988). Phantasia da Platone ai neoplatonici. En M. Fattori, M. Bianchi (Eds.), Phantasia-Imaginatio (Lessico Intellettuale Europeo. V Colloquio Internazionale Roma 9-11 gennaio, pp. 23-55). Roma: Edizioni dell'Ateneo.

-Cocking, J-M. (1991). Imagination. A study in the history of ideas. London: Routledge.

-Dilger, M. (1971). Der Enfluss der viktorinischen Anthropologie auf Bonawentura. Freiburg: Herder.

-Dillon, J. (1986). Plotinus and the transcendental imagination. En J. P. Mackey (Ed.), Religious Imagination (pp. 55-64). Edinburgh: Edinburgh University Press. 
-Dionsio Areopagita (2003a). Von den göttlichen Namen. En E. Stein, Wege der Gotteserkenntnis. Studie zu Dionysius Areopagita und Übersetzung seiner Werke (Edith Stein Gesamtausgabe (ESGA), 17, pp. 86-157). Freiburg: Herder.

-Dionisio Areopagita (2003b). Himmlische Hierarchie. En E. Stein, Wege der Gotteserkenntnis. Studie zu Dionysius Areopagita und Übersetzung seiner Werke (Edith Stein Gesamtausgabe (ESGA), 17, pp. 160-191). Freiburg: Herder.

-Dionisio Areopagita (2003c). Kirchliche Hierarchie. En E. Stein, Wege der Gotteserkenntnis. Studie zu Dionysius Areopagita und Übersetzung seiner Werke (Edith Stein Gesamtausgabe (ESGA), 17, pp. 194-244). Freiburg: Herder.

-Dionisio Areopagita (2003d). Mystische Theologie. En E. Stein, Wege der Gotteserkenntnis. Studie zu Dionysius Areopagita und Übersetzung seiner Werke (Edith Stein Gesamtausgabe (ESGA), 17, pp. 246-250). Freiburg: Herder.

-Dionisio Areopagita (2003e). Briefe. En E. Stein, Wege der Gotteserkenntnis. Studie zu Dionysius Areopagita und Übersetzung seiner Werke (Edith Stein Gesamtausgabe (ESGA), 17, pp. 252-277). Freiburg: Herder.

-Escoto Eriúgena, J. (1849). Commentarium In Sanctum Evangelium Secundum Joannem. En J. P. Migne, Patrologia Latina. Recuperado de http://www.documentacatholicaomnia.eu/02m/08150877,_Joannes_Scot us_Erigena,_Commentarium_In_Sanctum_Evangelium_Secundum_Joann em,_MLT.pdf

-Escoto Eriúgena, J. (2000). Komentarz do Ewangelii Jana (A. Kijewska, Trad. pol.). Kęty: Antyk.

-Escoto Eriúgena, J. (2005a). Teofania. En A. Kijewska, Eringena (A. Kijewska, Trad. pol., pp. 156-159). Warszawa: Wiedza Powszechna.

-Escoto Eriúgena, J. (2005b). Traktat o nicości. En A. Kijewska, Eriugena (A. Kijewska, Trad. pol., pp. 160-182). Warszawa: Wiedza Powszechna.

-Ficino, M. (2006). Platonica Theologia de immortalitate animorum. Recuperdao en http://bivio.signum.sns.it/bvWorkTOC.php?authorSign=FicinoMarsilio\& titleSign=Platonica'Theologia

-Ficino, M. (1993). Traktate zur Platonischen Philosophie (E. Blum, P.R. Blum, T. Leinkauf, Trads. alem. y Eds.). Berlin: Akademie Verlag.

-Hamesse, J. (1988). Imaginatio et phantasia chez le philosophes du 12 et 13 siècle. En M. Fattori, M. Bianchi (Eds.), Phantasia-Imaginatio (Lessico Intellettuale Europeo. V Colloquio Internazionale Roma 9-11 gennaio; pp. 153-184). Roma: Edizioni dell'Ateneo.

-Platón (1988). Sofista. En Platón, Diálogos (M. Santa Cruz, A. Vallejo, N. Cordero, Trads., Vol. 5, pp. 319-482). Madrid: Gredos.

-Platón (1992). Timeo. En Platón, Diálogos, (M. Durán, F. Lisi, Trads., Vol. 6, pp. 125-261). Madrid: Gredos.

-Plotino (1992). Enéadas I-II (J. Igal, Trad.). Madrid: Gredos.

-Plotino (1965). Enéada tercera (J. Miguez, Trad.). Buenos Aires: Aguilar.

-Plotino (1975). Enéada quinta (J. Miguez, Trad.). Buenos Aires: Aguilar.

-Plotino (1998). Enéadas V-VI (J. Igal, Trad.). Madrid: Gredos.

-Plotino (1967) Enéada sexta (J. Miguez, Trad.). Buenos Aires: Aguilar. 
-Pöltner, G. (1991). Der Begriff des Bildes bei Thomas von Aquin. En R. Heinrich, H. Vetter (Eds.), Bilder der Philosophie. Reflexionen über das Bildliche und die Phantasie (pp. 176-199). Wien, München: Oldenbourg Verlag.

-Ränsch, B. (1996). Phantasie. Welterkenntnis und Welterschaffung. Zur philosophischen Theorie der Einbildungskraft. Bonn: Bouvier Verlag.

-San Agustín (1946). Las Confesiones. En S. Agustín, Obras completas (A. Vega, Trad. esp. Vol. 2). Madrid: BAC.

-San Agustín (1992). The Confessions of Saint Augustine (J. O’Donnell, Ed.) Recuperado de http://www.stoa.org/hippo/noframe_entry.html

-Schütz, L. (1958). Thomas Lexikon. Recuperado de http://www.corpusthomisticum.org/tl.html

-Tatarkiewicz, W. (1962). Estetyka średniowieçna. En W.Tatarkiewicz, Historia estetyki (Vol. 2). Wrocław: Zakład Narodowy im. Ossolińskich.

-Tatarkiewicz, W. (2007). Historia de la estética. La estética medieval (D. Kurzyca, Trad.). Madrid: Akal.

-Volonté, P. (1997). Husserls Phänomenologie der Imagination. Zur Funktion der Phantasie bei der Konstitution von Erkenntnis. Freiburg-München: Verlag Karl Alber.

-Walerich, A. (2013). Jan od Krayża i Edyta Stein. Wyobraźnia i obraz w procesie mistycznym. Kraków: Księgarnia Akademicka.

-Watson, G. (1986). Imagination and Religion in classical thought. En J. P. Mackey (Ed.), Religious Imagination (pp. 29-54). Edinburgh: Edinburgh University Press.

Sumario: 1. Teología simbólica; 2. Razonamiento discursivo; 3. Ejercicio espiritual; 4. Teología mística; Referencias. 